\title{
Pulmonary Veno-Occlusive Disease: An 80-Year-Old Mystery
}

\author{
Zhehao Dai Yoshiyuki Matsui \\ Tohoku University School of Medicine, Sendai, Japan
}

\section{Key Words}

Pulmonary veno-occlusive disease $\cdot$ Pulmonary arterial hypertension - BMPR2 gene - Occult alveolar hemorrhage . High-resolution computed tomography

\begin{abstract}
Pulmonary veno-occlusive disease (PVOD) is a rare form of pulmonary hypertension which occurs in 0.1-0.2 people per million. Its etiology is still poorly understood but is related to several risk factors. The histopathology of PVOD is characterized by intimal fibrosis narrowing or the occlusion of small pulmonary veins or venules. A definitive diagnosis requires a surgical biopsy, which is a risky procedure. Thus, the diagnosis must be based on high clinical suspicion and the results of various diagnostic tests, mainly high-resolution computed tomography, pulmonary function tests, bronchoalveolar lavage, and right heart catheterization. The definitive treatment is limited to lung transplantation. Several pulmonary arterial hypertension-specific agents may cause pulmonary edema in PVOD. However, the cautious use of such medications in selected patients, and surgical or mechanical supports, may successfully bridge patients to transplantation. Given the scant knowledge regarding this entity, future studies with a focus on elucidating the etiology and establishing the optimal treatment are required, as is further development in diagnosis.

(c) 2014 S. Karger AG, Basel
\end{abstract}

\section{Introduction}

Pulmonary arterial hypertension (PAH) is a severe entity characterized by elevated pulmonary artery (PA) pressure which frequently leads to right heart failure and death $[1,2]$. Besides conventional therapies, several targeted vasodilators have been developed for PAH in relation to the molecular pathways in PA constriction [3]. Despite the recent progress in $\mathrm{PAH}$ treatment, there is still no established curative medical therapy and thus these patients have a poor prognosis $[1,4]$. Pulmonary veno-occlusive disease (PVOD) is a rare disease related to PAH. Unlike PAH, PVOD affects the postcapillary venous vessels [5] and presents a worse outcome [6, 7]. Some studies have suggested that PVOD and PAH, along with pulmonary capillary hemangiomatosis $(\mathrm{PCH})$, may represent different phenotypic manifestations of a spectrum of a single disease $[4,5,8]$. Because of pathological and clinical differences compared to other PAHs, PVOD together with $\mathrm{PCH}$ were categorized into a separate but associated group in relation to $\mathrm{PAH}$, i.e. group 1', in the 4th World Symposium on Pulmonary Hypertension held in Dana Point, Calif., USA [2].

Although 8 decades have passed since the first description by Dr. Julius Höra [9] in 1934, PVOD remains poorly understood, especially in terms of its pathogenesis and treatment. Most of the insights into this disease have been

\section{KARGER}

E-Mail karger@karger.com www.karger.com/res
(C) 2014 S. Karger AG, Basel

0025-7931/14/0882-0148\$39.50/0
Zhehao Dai

Tohoku University School of Medicine

1-1 Seiryo-machi, Aoba-ku, Sendai 980-8575 (Japan)

E-Mail taitetsukou@ cardio.med.tohoku.ac.jp 
obtained via single case reports and a few retrospective studies of case series. With difficulty, our knowledge regarding this entity has been gradually increasing thanks to investigators' persistent efforts. This review summarizes the current knowledge on PVOD, with a special focus on recent progress.

\section{Epidemiology}

The incidence and prevalence of PVOD are not clearly known. This is not only because it is rarely reported but also because it is often misdiagnosed as precapillary pulmonary hypertension. PVOD accounts for approximately $10 \%$ of patients diagnosed with idiopathic $\mathrm{PAH}[10$ 12]. Thus, the annual incidence is estimated to be about $0.1-0.2$ cases per million in the general population [1012]. This number, however, may be underestimated because PVOD is also misdiagnosed as other forms of pulmonary hypertension, such as chronic thromboembolic pulmonary hypertension. In contrast to idiopathic $\mathrm{PAH}$, which predominantly affects females, PVOD occurs almost equally in males and females $[6,7,13,14]$. The age at diagnosis presents a wide range, from immediately after birth to the 7 th decade of life.

\section{Etiology}

The etiology of PVOD remains largely unclear because many factors, such as the complexity of the disease and the difficulty of obtaining a biopsy due to the position of the lesion sites, have prevented researchers from studying this entity. There is no clue suggesting that PVOD develops through a single etiology. It is known to be inherited, or associated with congenital heart diseases, or even acquired. In addition to previous case reports, recent case series have provided more information $[6,7]$.

\section{Genetic Factors}

Several publications reporting the occurrence of PVOD in siblings have suggested a genetic risk factor [13, 15]. Three decades after that hypothesis, Runo et al. [8] reported a germline mutation in the BMPR2 gene in a PVOD patient with a family history. Subsequently, mutations in the BMPR2 gene were reported in more patients [6]. Since mutations in the BMPR2 gene are also involved in PAH, a similarity between PAH and PVOD was suggested [2]. In a quite recent report, Eyries et al. [16], using whole-exome sequencing, detected recessive mutations in the EIF2AK4 gene that cosegregated with PVOD in all 13 families studied, as well as biallelic EIF2AK4 mutations in 5 of 20 sporadic PVOD cases.

\section{Epigenetic Factors}

Recently, Perros et al. [17] reported an epigenetic involvement in PVOD. The granulysin (GNLY) gene was shown to be hypermethylated in gDNA from the lungs and blood of patients with PVOD compared to patients with PAH. Consequent alterations in the circulating cytotoxic cell subpopulations were also observed, which might contribute not only to the understanding of the etiology but also to the development of diagnostic tools.

\section{Infection}

Infection has been hypothesized as a cause of PVOD since the first report, but this has not been supported by sufficient direct evidence. Flu-like symptoms [18], clinical features suggesting a recent infection of rubella [19], toxoplasma [20], and autoptic findings indicating a viral infection [21] have been noted in some patients. PVOD has also been reported in 2 human immunodeficiency virus-infected patients $[22,23]$.

\section{Toxic Exposures}

Anorexigen exposure is a risk factor for $\mathrm{PAH}$ [24], but it has been reported in only 1 PVOD case [6]. Instead, many patients have undergone chemotherapies for various malignancies before the diagnosis of PVOD, with regimens including cisplatin, bleomycin, mitomycin, $\mathrm{BNCU}$, mechlorethamine, vincristine, procarbazine, and cyclophosphamide $[25,26]$. Accumulating evidence suggests that PVOD is a complication of hematopoietic stem cell transplantation, both allogeneic and autologous, from bone marrow, peripheral blood, and cord blood [27-30]. It is worth discussing how much transplantation itself contributes to PVOD, because chemotherapy, as mentioned above, and radiation, as constituents of the pretreatment for hematopoietic stem cell transplantation, have both been reported to be associated with PVOD [31].

The presence of a smoking habit is comparable between PVOD and idiopathic PAH patients $[6,32]$; however, heavier smoking habits (more tobacco exposure) have been noted in PVOD compared to idiopathic PAH patients [6].

\section{Autoimmune Diseases}

Autoimmune diseases may cause thrombosis and tissue fibrosis, which could partially explain the pathologi- 
cal findings in PVOD [10], but there is not sufficient documentation, especially regarding their exact involvement in the etiology. The previously reported autoimmune diseases associated with PVOD are largely diverse and include focal granulomatous venulitis $[33,34]$, generalized venulitis such as in the setting of sarcoidosis or Langerhans' cell granulomatosis [35-37], Sjögren's syndrome [38], Felty's syndrome [39], mixed connective tissue disease [40], systemic lupus erythematosus [41], Hashimoto's thyroiditis [42], and limited or diffuse systemic scleroderma [43-45]. Gunther et al. [43] demonstrated in a recent study that, out of 26 precapillary pulmonary hypertension cases associated with systemic scleroderma, $16(61.5 \%)$ presented $\geq 2$ radiographic signs of PVOD on high-resolution computed tomography (HRCT). Interestingly, 8 of them experienced pulmonary edema after the initiation of PAH-targeted therapy. These results indicate that PVOD associated with scleroderma may be frequently misdiagnosed as PAH, suggesting the need for a cautious differential diagnosis when precapillary pulmonary hypertension is seen in a scleroderma patient.

\section{Miscellaneous}

Investigators have also reported other associations besides those mentioned above. Several infants with congenital heart disease, such as hypoplastic left heart syndrome and partial anomalous pulmonary vein connection, have been reported [46, 47]. These cases are considered to be due not only to the congenital obstruction of pulmonary venous return, because a case has been documented in association with unilateral pulmonary venous atresia occurring in the lung contralateral to PVOD [48]. A possible explanation could be the involvement of endothelial damage and coagulopathy, which is supported by 2 publications reporting 3 PVOD patients in association with oral contraceptives $[49,50]$, a description of PVOD in pregnancy [51], and other studies [27].

\section{Pathology}

As its name suggests, the histopathology of PVOD is represented by fibrous remodeling of the intima, which narrows or occludes small pulmonary veins or venules. The fibrous tissue could be either loose and edematous or dense and collagen rich. Large veins are sometimes affected, although not as frequently as small ones [14]. The media of the affected veins may present a normal thickness or show arterialization resulting from smooth muscle hypertrophy and an increase in elastic fiber. Calcium- encrusted elastic fiber may also be seen in some cases [52]. Recognizable thrombi or intraluminal fibrous septa suggestive of recanalization are observable in most cases.

Despite the 'venous' in its name, PVOD often exhibits lesions in pulmonary capillaries and arterioles or arteries. Medial hypertrophy and intimal fibrosis may be present in small arteries, mimicking PAH. However, plexiform lesions, a characteristic finding in idiopathic $\mathrm{PAH}$, are usually absent $[10-12,53]$. In some cases, alveolar capillaries may demonstrate dilation and congestion, resulting in an angioma-like appearance [52]. It is noteworthy that $\mathrm{PCH}$ can be distinguished from PVOD by its disordered capillary proliferation and the absence of venous lesions. Interestingly, a recent report by Lantuejoul et al. [5] demonstrated that, in a review of specimens from 35 previously diagnosed PVOD or PCH patients, $73 \%$ of the diagnosed PVOD patients and $80 \%$ of the diagnosed $\mathrm{PCH}$ cases exhibited each other's histopathological features. These findings support the hypothesis that PVOD and $\mathrm{PCH}$ may represent 2 phenotypic manifestations of a spectrum of a single disease [2].

With a focus on lymphoid tissue, Thomas de Montpreville et al. [54] reported that lymphatic congestion, vascular transformation of the sinuses, intrasinusal hemorrhage with erythrophagocytosis and lymphoid follicular hyperplasia occur more frequently in PVOD than in pulmonary hypertension of other causes.

Other commonly observed lesions are interstitial edema and fibrosis. Hemorrhage may also be found in and around these areas, along with hemosiderotic changes [14]. Hemorrhage is of diagnostic importance because it allows detection of the disease by bronchoalveolar lavage (BAL) [32], which will be discussed below.

\section{Clinical Features and Diagnosis}

It is impossible to diagnose PVOD only based on its symptoms. Patients present with nonspecific symptoms that are also observed in PAH of other causes. Most patients complain of dyspnea on exertion. Some patients suffer from chest pain, cough (which is often nonproductive), cyanosis, and, rarely, syncope [5, 7]. Hemoptysis occurred in 8 out of 20 patients in a case series [5] but in only 1 out of 24 patients in another series [6]. Jones et al. [37] described a sarcoidosis-associated patient with hemoptysis in detail. Patients who develop right heart failure may present with lower extremity edema, a prominent $\mathrm{P} 2$ component of the 2 nd heart sound, and a murmur of tricuspid regurgitation [7]. Crackles on chest 
Fig. 1. HRCT of the chest in PVOD. a HRCT of the chest showing marked ground-glass opacities with a centrilobular pattern, poorly defined nodular opacities, septal lines, and minimal right pleural effusion. b HRCT of the chest showing mediastinal lymph node enlargement (white dotted lines). Reproduced from Montani et al. [56], with permission from the European Respiratory Society.

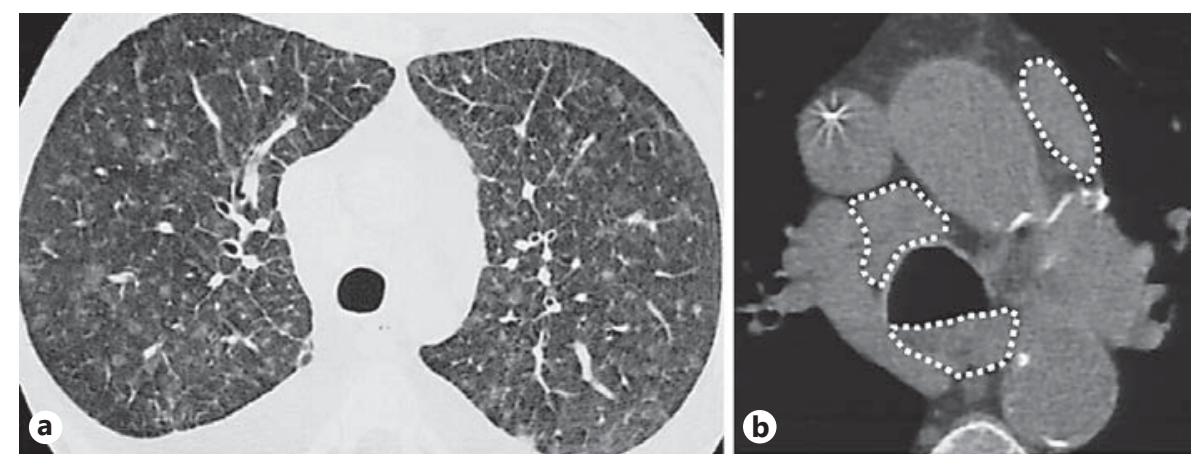

auscultation may indicate pulmonary infiltrates [10]. Clubbing was once thought to be more associated with PVOD than with PAH [7]. A recent study confirmed this tendency, but without statistical significance [6]. Orthopnea has also been reported in PVOD, though it is uncommon in other forms of PAH [7]. Pleural effusion was thought to be more frequent in PVOD than in other PAH a decade ago, but this was disproved by recent studies using HRCT $[6,55]$.

\section{Diagnostic Approach}

A definitive diagnosis of PVOD requires a surgical biopsy, which is an invasive, and dangerous procedure. Thus, clinicians often avoid this procedure and seek alternative methods. Fortunately, the diagnostic value of HRCT, pulmonary function tests, BAL, and flow cytometry for detecting alterations in cytotoxic cell subpopulations in PVOD is in the process of being established.

\section{Right Heart Catheterization}

Since PVOD shares many symptoms with PAH, clinicians seldom suspect PVOD immediately. A right heart catheterization is always performed to examine the hemodynamics, in which pulmonary hypertension is diagnosed by a mean PA pressure $\geq 25 \mathrm{~mm} \mathrm{Hg}$ at rest. The pulmonary wedge pressure (PWP) in PVOD remains within the normal range $(\leq 15 \mathrm{~mm} \mathrm{Hg})$ or is slightly elevated $[6,7]$. It is these hemodynamic characteristics, along with the symptoms, that lead to the misdiagnosis of $\mathrm{PAH}$. However, one may argue that this precapillary pattern is discrepant with the post-capillary lesions in PVOD. A widely accepted theory is that the PWP reflects the pressure in relatively large veins of a diameter similar to that of the occluded PA. These veins are usually larger than, and distal from, the affected small veins and therefore have normal pressures [56]. In light of this explanation, patients with a slightly elevated PWP may develop large vein lesions. An elevated true capillary pressure (not PWP) may be useful in the diagnosis of PVOD. However, 30 years after the establishment of the calculation principle [57], the estimation of true capillary pressure is still not applied clinically, with the exception of a few studies.

\section{Radiology}

Though less informative compared to computed tomography, chest radiography is still routinely done in patients suspected of having pulmonary hypertension. In addition to the common findings suggesting pulmonary hypertension, such as right ventricular enlargement and PA dilation, chest radiographs in PVOD may show Kerley $B$ lines and a normal left atrium, distinguishing it from pulmonary hypertension owing to left heart disease [58].

HRCT is the most important imaging modality to discern between PVOD and PAH. Consistent with chest radiographs, chest HRCT demonstrates right ventricular hypertrophy and PA dilation in most patients $[55,59]$. The triad of ground-glass opacities, particularly with a centrilobular pattern, thickened interlobular septa, and mediastinal lymphadenopathy, suggests PVOD rather than PAH with a high sensitivity and specificity [55] (fig. 1). Montani et al. [6] reported that the presence of 2 or more of the abnormalities listed above is $75 \%$ sensitive and $85 \%$ specific for the detection of PVOD in patients with presumed PAH. Concerning the size of the centrilobular ground-glass opacities, Miura et al. [60] demonstrated in a recent publication that smaller ground-glass opacities might differentiate PVOD from PCH. In addition, the presence of pleural effusion and pericardial effusion is comparable between PVOD and PAH [55].

As stated in recent European Respiratory Society/European Society of Cardiology guidelines [4], unmatched perfusion defects on ventilation/perfusion scans may also occur in PVOD, like in chronic thromboembolic pulmonary hypertension. This is not a common finding in 
PVOD (about 7\%) $[7,61]$ and was recently detected to occur in PAH as well, with an incidence comparable to that in PVOD [61]. The guidelines call attention to the possibility that PVOD is sometimes misdiagnosed as chronic thromboembolic pulmonary hypertension, rather than suggesting the diagnostic value of ventilation/perfusion scans in PVOD.

\section{Pulmonary Function Tests}

A decreased diffusion capacity for carbon monoxide (DLCO) has been described not only in PAH but also in PVOD [62]. Based on a case series of 24 PVOD patients, Montani et al. [6] concluded that the DLCO and the DLCO/alveolar volume ratio were decreased in both PVOD and PAH and were significantly lower in PVOD. Some patients may present restrictive ventilatory defects [7]. The case series mentioned above, however, showed that the averages of the forced expiratory volume in $1 \mathrm{~s}$ $\left(\mathrm{FEV}_{1}\right)$ and the $\mathrm{FEV}_{1} /$ vital capacity ratio were within the normal ranges and were comparable to those in $\mathrm{PAH}$ [6].

\section{$B A L$}

Considering the alveolar hemorrhage on histological examination, Rabiller et al. [32] performed BAL in 8 PVOD and 11 idiopathic PAH patients without hemoptysis with the hypothesis that PVOD patients may have occult alveolar hemorrhage. The Golde score was used to assess the alveolar hemorrhage; 200-300 macrophages were counted and each cell was graded for hemosiderin on a scale of $0-4$. A mean score for 100 cells was used, with 0 being the minimum and 400 the maximum score, and scores between 0 and 20 were considered normal [63]. In the subsequent cytological analyses, the BAL fluid of PVOD patients was characterized by a higher percentage of hemosiderin-laden macrophages and, consequently, an elevated Golde score, indicating occult alveolar hemorrhage. Only 1 idiopathic PAH patient exhibited an elevated Golde score. In contrast, only 1 PVOD patient had a Golde score within the normal range. This study suggested the possible application of BAL in the diagnosis of PVOD, which had a sensitivity of $88 \%$ and a specificity of $91 \%$ when the Golde score cutoff was set at 20 . A successful application in a suspected case was reported afterwards [64].

\section{Flow Cytometry}

In a recent publication, Perros et al. [17] reported that the GNLY gene was hypermethylated in gDNA from the lungs and blood of patients with PVOD compared to patients with $\mathrm{PAH}$, which was associated with alterations in cytotoxic cell subpopulations. The study uncovered a new pathway in the etiology of PVOD and indicated a new diagnostic technique. However, the complicated alterations in cytotoxic cell subpopulations made it difficult to define criteria to differentiate PVOD from PAH by flow cytometry analyses. In order to obtain sufficient data and evidence, future research is still required.

\section{Other Findings of Diagnostic Usefulness}

Studies have also shown a reduced partial pressure of arterial oxygen $\left(\mathrm{PaO}_{2}\right)$ in PVOD (even lower than that in $\mathrm{PAH})[6,7]$. In addition, during the 6-min walk test, rather than the distance, a lower nadir arterial oxygen saturation measured by pulse oxymetry could be of diagnostic value [6]. Acute vasodilator testing is useful in predicting the response to treatment in $\mathrm{PAH}[1,4]$ but may cause pulmonary edema in PVOD [7] and thus needs to be carefully conducted. Pulmonary edema could also develop after the initiation of vasodilators, including calcium channel blockers (CCBs), bosentan, epoprostenol, and sildenafil, in nearly one half of patients $[6,7,56]$. Acute pulmonary edema after administration of these agents in a patient suspected of having PAH is a clue for the clinician to doubt his/her diagnosis and reevaluate the patient for PVOD, like Masters and Bennett [65] did.

\section{Prognosis and Treatments}

The prognosis of PVOD is dismal, with a reported 1 -year mortality rate of 72\% [7]. Most patients die within 2 years of the diagnosis [66]. A recent report described the longest survival, i.e. $>15$ years after the initial admission [67]. Montani et al. [6] compared PVOD and PAH patients with similar baseline hemodynamic and 6-min walk test findings and New York Heart Association (NYHA) functional classes and found that PVOD patients had extremely worse outcomes compared to PAH patients. In recent years, physicians have reported progress in treating PVOD in single case reports or case series. Despite those efforts, lung transplantation remains the only cure, and an early decision of transplantation is considered crucial.

\section{Conventional Therapies}

Continuous oxygen therapy is a class I recommendation for $\mathrm{PAH}$ patients whose $\mathrm{PaO}_{2}$ is consistently $<60 \mathrm{~mm}$ $\mathrm{Hg}(8.0 \mathrm{kPa})$ [4]. Clinicians consider the initiation of oxygen as treatment for the symptoms of PVOD, as well as to prevent exacerbations [56]. Although we should not 
ignore the lack of evidence indicating a mortality benefit of oxygen therapy, this choice is never wrong since the adverse effects are few.

Idiopathic $\mathrm{PAH}$ patients benefit from oral anticoagulants due to their effect against thrombotic lesions [68]. Guidelines recommend $\mathrm{PAH}$ patients who receive intravenous (i.v.) prostacyclins to undergo anticoagulation in the absence of contraindications [4]. Although there are no data regarding anticoagulation in PVOD, the use of warfarin has been adopted from PAH guidelines because obvious or recanalized thrombi are seen in the pathology of PVOD, like in idiopathic PAH [14]. However, a recent study emphasizing the occult alveolar hemorrhage in PVOD urged physicians to be cautious when subscribing warfarin [32].

\section{PAH-Targeted Therapies}

$\mathrm{PAH}$-targeted therapies such as CCBs, endothelin receptor antagonists, phosphodiesterase type 5 inhibitors, and prostacyclins have an established and important role in the treatment of PAH [4]. However, these cannot be simply applied in the treatment of PVOD because of the lack of evidence as well as the reports of adverse effects, like pulmonary edema, after the initiation of these agents. Theoretically, when the pulmonary arterioles dilate and the resistance of the pulmonary veins remains fixed, the transcapillary hydrostatic pressure might increase and pulmonary edema may occur. As a result, the European Respiratory Society/European Society of Cardiology guidelines recommend management in centers with extensive experience when administrating these agents (class IIa, level C) [4]. The recently reported cases on the use of these therapies in PVOD have provided slightly more information.

CCBs, such as nifedipine, are widely prescribed in cases of systemic hypertension as well as in $\mathrm{PAH}$ patients presenting with a positive acute vasodilator response. In PVOD, their use has been reported in only a few publications. Salzman and Rosa [69] documented a long survival with nifedipine. In the case series reported by Holcomb et al. [7], of 8 patients who were on CCBs, only 1 had sustained clinical improvement but 6 experienced pulmonary edema. Montani et al. [6] also reported that 1 out of 24 patient experienced pulmonary edema. Based on these publications, CCBs appear not to be a good choice. However, the documented cases are few and the conditions are varies. Like with epoprostenol (described below), cautious administration might help.

Epoprostenol is a powerful agent in the treatment of $\mathrm{PAH}$ and it has been proven to improve survival in idio- pathic PAH in randomized trials [4]. Among the vasodilators, epoprostenol has the most accumulated evidence in the management of PVOD. It was reported to cause pulmonary edema in one case in 1998 [70]. Holcomb et al. [7] demonstrated that, of 3 patients receiving i.v. epoprostenol, 1 developed pulmonary edema. Furthermore, Montani et al. [6] reported that, of 11 patients taking epoprostenol, 5 experienced episodes of pulmonary edema. In spite of the probability of developing pulmonary edema of approximately $40 \%$, physicians have few choices for the treatment of PVOD and have to prescribe epoprostenol in some conditions. Fortunately, 2 recent studies indicated its safety and efficacy when used with caution. Montani et al. [71] reported in 2009 that, among 12 PVOD patients undergoing i.v. epoprostenol therapy with slow dose increases and high doses of diuretics, only 1 developed mild reversible pulmonary edema in the following 3-4 months. Improvement was observed in the NYHA functional class and cardiac index but not in the 6-min walk test. Nine patients were successfully bridged to lung transplantation. Quite recently, Ogawa et al. [72] documented $6 \mathrm{PVOD}$ patients and $2 \mathrm{PCH}$ patients undergoing i.v. epoprostenol treatment. With cautious observation, the authors stopped increasing the dose of epoprostenol and added diuretics or catecholamine when signs of deterioration such as pulmonary edema were noticed. The subjects showed temporary improvement in their NYHA functional class, 6-min walk distance, plasma brain natriuretic peptide level, and cardiac index, but not in their PA pressure or pulmonary vascular resistance. Epoprostenol worked as a bridge to lung transplantation in 4 subjects, 3 of whom had PVOD. As indicated by these studies, epoprostenol may result in improvement for a short time, but its long-term efficacy is still unknown. The current opinion, therefore, is that it may at least be safely used with intensive observation as a bridge to transplantation.

Bosentan, an endothelin receptor antagonist, has been reported to achieve improvement in very few cases [64, 73]. However, it is also on the list of agents which produce pulmonary edema at a rate of $33 \%$ ( 2 out of 6 patients) [6]. Ye et al. [73] reported one patient in whom the use of bosentan turned out to be safe and effective when administrated with diuretics. Sildenafil, a phosphodiesterase type 5 inhibitor, has even less reported evidence. It has been demonstrated to be effective in only 3 cases to date [74-76]. In addition, Montani et al. [77] observed an exacerbation of symptoms and the occurrence of pulmonary edema after the administration of sildenafil in addition to bosentan in a patient and recommended close 
monitoring and the use of diuretics to reduce the risk. Other new PAH-targeted therapies, such as tadalafil, have not been reported in PVOD yet.

Pulmonary edema is the largest obstacle for the employment of PAH-targeted agents in PVOD. However, no clinical, functional, or hemodynamic characteristics have been proven to predict the development of pulmonary edema [6].

\section{Immunosuppressive Agents}

Immunosuppressive medications, such as glucocorticoids and antimetabolites, may result in the clinical improvement of $\mathrm{PAH}$ associated with connective tissue disease [4]. They have also been employed in PVOD, particularly among patients with autoimmune diseases, resulting in clinical improvement [37, 38, 45, 78]. However, the experiences have been poor and, more importantly, no data support the wide use of these agents in PVOD in the absence of autoimmune diseases.

\section{Lung Transplantation}

Lung transplantation is considered the only cure for $\mathrm{PVOD}$, as in PAH. Thus, the guidelines recommend a referral to a transplant center as soon as a proper diagnosis is established [4]. Although there is only one report of recurrence after heart-lung transplantation in a 26year-old man [79], no further such cases have been documented.

To bridge patients to transplantation, besides the medications described above, surgical and mechanical support may also be useful. Strueber et al. [80] demonstrated that a lung assist device connected via the PA main trunk and left atrium successfully bridged 4 patients to bilateral lung transplantation or heart-lung transplantation. Hoopes et al. [81] recently developed combined atrial septostomy and venovenous extracorporeal membrane oxygenation as a mechanical support, which resulted in hemodynamic stabilization in a patient.

\section{Other Medications}

In hepatic veno-occlusive disease, defibrotide is used successfully as an investigational drug. It produces a favorable response in patients with hepatic veno-occlusive disease after stem cell transplantation and even has prophylactic effects $[82,83]$. Defibrotide works via heterogeneous effects on blood coagulation and fibrinolysis. Because of the lack of evidence, its use is not recommended in PVOD [10]. Nevertheless, one case report from Willems et al. [84] suggested its potential benefits in PVOD, but this still requires further investigation.
As indicated by several recent trials $[85,86]$, imatinib may improve the exercise capacity and hemodynamics as an add-on therapy in PAH, possibly through the inhibition of platelet-derived growth factor receptor. In PVOD, the involvement of platelet-derived growth factor is unknown, and the evidence remains controversial. Overbeek et al. [87] reported a patient who experienced rapid relief of symptoms after the addition of imatinib to epoprostenol. On the contrary, Koiwa et al. [88] described a case that was refractory to imatinib. Kataoka et al. [89] reported another case which did not respond to imatinib but did improve with sorafenib, a multikinase inhibitor which is usually used in the treatment of kidney cancer.

\section{Conclusions and Future Perspectives}

PVOD is still a rare and poorly understood subgroup of pulmonary hypertension despite investigators' persistent efforts over the past 8 decades. PAH-targeted therapies are currently applied in PVOD with caution, although the evidence is still not sufficient. Their limited benefit and the risk of pulmonary edema leave lung transplantation as the only cure. The prognosis is still poor, emphasizing the importance of an early diagnosis. Fortunately, several diagnostic tools have been developed, among which HRCT has the most clinical importance. By optimizing these tools, clinicians are expected to be able to reduce the incidence of misdiagnosis of PVOD. Future studies are required to further elucidate the underlying etiology or etiologies, as well as to determine optimal therapies.

\section{Acknowledgement}

This work was supported in part by a Grant-in-Aid from Ministry of Education, Culture, Sports, Science and Technology of Japan.

\section{Financial Disclosure and Conflicts of Interest}

The authors have no conflicts of interest to disclose. 


\section{References}

$>1$ Humbert M, Sitbon O, Simonneau G: Treatment of pulmonary arterial hypertension. $\mathrm{N}$ Engl J Med 2004;351:1425-1436.

-2 Simonneau G, Robbins IM, Beghetti M, Channick RN, Delcroix M, Denton CP, Elliott CG, Gaine SP, Gladwin MT, Jing ZC, Krowka MJ, Langleben D, Nakanishi N, Souza R: Updated clinical classification of pulmonary hypertension. J Am Coll Cardiol 2009;54:S43S54.

3 Fukumoto Y, Shimokawa H: Recent progress in the management of pulmonary hypertension. Circ J 2011;75:1801-1810.

-4 Galie N, Hoeper MM, Humbert M, Torbicki A, Vachiery JL, Barbera JA, Beghetti M, Corris P, Gaine S, Gibbs JS, Gomez-Sanchez MA, Jondeau G, Klepetko W, Opitz C, Peacock A, Rubin L, Zellweger M, Simonneau G: Guidelines for the diagnosis and treatment of pulmonary hypertension. Eur Respir J 2009;34: 1219-1263.

$>5$ Lantuejoul S, Sheppard MN, Corrin B, Burke MM, Nicholson AG: Pulmonary veno-occlusive disease and pulmonary capillary hemangiomatosis: a clinicopathologic study of 35 cases. Am J Surg Pathol 2006;30:850-857.

$>6$ Montani D, Achouh L, Dorfmuller P, Le Pavec J, Sztrymf B, Tcherakian C, Rabiller A, Haque R, Sitbon O, Jais X, Dartevelle P, Maitre S, Capron F, Musset D, Simonneau G, Humbert M: Pulmonary veno-occlusive disease: clinical, functional, radiologic, and hemodynamic characteristics and outcome of 24 cases confirmed by histology. Medicine (Baltimore) 2008;87:220-233.

7 Holcomb BW Jr, Loyd JE, Ely EW, Johnson J, Robbins IM: Pulmonary veno-occlusive disease: a case series and new observations. Chest 2000;118:1671-1679.

$>8$ Runo JR, Vnencak-Jones CL, Prince M, Loyd JE, Wheeler L, Robbins IM, Lane KB, Newman JH, Johnson J, Nichols WC, Phillips JA 3rd: Pulmonary veno-occlusive disease caused by an inherited mutation in bone morphogenetic protein receptor II. Am J Respir Crit Care Med 2003;167:889-894.

9 Höra J: Histologie der klinischen 'primaren Pulmonalsklerose'. Frankfurter Z Pathol 1934;47:100-108.

10 Mandel J, Mark EJ, Hales CA: Pulmonary veno-occlusive disease. Am J Respir Crit Care Med 2000;162:1964-1973.

11 Montani D, O’Callaghan DS, Savale L, Jais X, Yaici A, Maitre S, Dorfmuller P, Sitbon O, Simonneau G, Humbert M: Pulmonary venoocclusive disease: recent progress and current challenges. Respir Med 2010;104(suppl 1):S23-S32.

$>12$ Huertas A, Girerd B, Dorfmuller P, O'Callaghan D, Humbert M, Montani D: Pulmonary veno-occlusive disease: advances in clinical management and treatments. Expert Rev Respir Med 2011;5:217-229.
13 Thadani U, Burrow C, Whitaker W, Heath D: Pulmonary veno-occlusive disease. Q J Med 1975;44:133-159.

14 Wagenvoort CA, Wagenvoort N: The pathology of pulmonary veno-occlusive disease. Virchows Arch A Pathol Anat Histol 1974; 364:69-79.

15 Rosenthal A, Vawter G, Wagenvoort CA: Intrapulmonary veno-occlusive disease. Am J Cardiol 1973;31:78-83.

16 Eyries M, Montani D, Girerd B, Perret C, Leroy $A$, Lonjou $C$, Chelghoum $\mathrm{N}$, Coulet $\mathrm{F}$, Bonnet D, Dorfmuller P, Fadel E, Sitbon O, Simonneau G, Tregouet DA, Humbert M, Soubrier F: EIF2AK4 mutations cause pulmonary veno-occlusive disease, a recessive form of pulmonary hypertension. Nat Genet 2014; 46:65-69.

17 Perros F, Cohen-Kaminsky S, Gambaryan N, Girerd B, Raymond N, Klingelschmitt I, Huertas A, Mercier O, Fadel E, Simonneau G, Humbert M, Dorfmuller P, Montani D: Cytotoxic cells and granulysin in pulmonary arterial hypertension and pulmonary veno-occlusive disease. Am J Respir Crit Care Med 2013; 187:189-196.

18 Brewer DB, Humphreys DR: Primary pulmonary hypertension with obstructive venous lesions. Br Heart J 1960;22:445-448.

19 Crane JT, Grimes OF: Isolated pulmonary venous sclerosis: a cause of cor pulmonale. J Thorac Cardiovasc Surg 1960;40:410-416.

20 Stovin PG, Mitchinson MJ: Pulmonary hypertension due to obstruction of the intrapulmonary veins. Thorax 1965;20:106-113.

21 McDonnell PJ, Summer WR, Hutchins GM: Pulmonary veno-occlusive disease: morphological changes suggesting a viral cause. JAMA 1981;246:667-671.

22 Escamilla R, Hermant C, Berjaud J, Mazerolles C, Daussy X: Pulmonary veno-occlusive disease in a HIV-infected intravenous drug abuser. Eur Respir J 1995;8:1982-1984.

23 Ruchelli ED, Nojadera G, Rutstein RM, Rudy B: Pulmonary veno-occlusive disease: another vascular disorder associated with human immunodeficiency virus infection? Arch Pathol Lab Med 1994;118:664-666.

24 Humbert M, Nunes H, Sitbon O, Parent F, Herve P, Simonneau G: Risk factors for pulmonary arterial hypertension. Clin Chest Med 2001;22:459-475.

25 Lombard CM, Churg A, Winokur S: Pulmonary veno-occlusive disease following therapy for malignant neoplasms. Chest 1987;92:871876.

26 Knight BK, Rose AG: Pulmonary veno-occlusive disease after chemotherapy. Thorax 1985; 40:874-875.

27 Bunte MC, Patnaik MM, Pritzker MR, Burns LJ: Pulmonary veno-occlusive disease following hematopoietic stem cell transplantation: a rare model of endothelial dysfunction. Bone Marrow Transplant 2008;41:677-686.
28 Gutman JA, Allen CT, Madtes DK, Schramm J, Delaney C: Pulmonary veno-occlusive disease following reduced-intensity cord blood transplantation. Bone Marrow Transplant 2008;42:559-561.

29 Williams LM, Fussell S, Veith RW, Nelson S, Mason CM: Pulmonary veno-occlusive disease in an adult following bone marrow transplantation: case report and review of the literature. Chest 1996;109:1388-1391.

30 Troussard X, Bernaudin JF, Cordonnier C, Fleury J, Payen D, Briere J, Vernant JP: Pulmonary veno-occlusive disease after bone marrow transplantation. Thorax 1984;39: 956-957.

31 Kramer MR, Estenne M, Berkman N, Antoine M, de Francquen P, Lipski A, Jacobovitz D, Lafair J: Radiation-induced pulmonary venoocclusive disease. Chest 1993;104:1282-1284.

32 Rabiller A, Jais X, Hamid A, Resten A, Parent F, Haque R, Capron F, Sitbon O, Simonneau G, Humbert M: Occult alveolar haemorrhage in pulmonary veno-occlusive disease. Eur Respir J 2006;27:108-113.

33 Crissman JD, Koss M, Carson RP: Pulmonary veno-occlusive disease secondary to granulomatous venulitis. Am J Surg Pathol 1980;4: 93-99.

-34 Dwyer N, Smith R, Challis D, Reid D, Kilpatrick D: Granulomatous angiitis leading to a pulmonary veno-occlusive disease-like picture. Eur Respir J 2009;33:666-669.

35 Hoffstein V, Ranganathan N, Mullen JB: Sarcoidosis simulating pulmonary veno-occlusive disease. Am Rev Respir Dis 1986;134: 809-811.

36 Hamada K, Teramoto S, Narita N, Yamada E, Teramoto K, Kobzik L: Pulmonary veno-occlusive disease in pulmonary Langerhans' cell granulomatosis. Eur Respir J 2000;15:421423.

37 Jones RM, Dawson A, Jenkins GH, Nicholson AG, Hansell DM, Harrison NK: Sarcoidosisrelated pulmonary veno-occlusive disease presenting with recurrent haemoptysis. Eur Respir J 2009;34:517-520.

38 Naniwa T, Takeda Y: Long-term remission of pulmonary veno-occlusive disease associated with primary Sjogren's syndrome following immunosuppressive therapy. Mod Rheumatol 2011;21:637-640.

>39 Devereux G, Evans MJ, Kerr KM, Legge JS: Pulmonary veno-occlusive disease complicating Felty's syndrome. Respir Med 1998;92: 1089-1091.

40 Zhang L, Visscher D, Rihal C, Aubry MC: Pulmonary veno-occlusive disease as a primary cause of pulmonary hypertension in a patient with mixed connective tissue disease. Rheumatol Int 2007;27:1163-1165.

41 Kishida Y, Kanai Y, Kuramochi S, Hosoda Y: Pulmonary venoocclusive disease in a patient with systemic lupus erythematosus. J Rheumatol 1993;20:2161-2162. 
-42 Kokturk N, Demir N, Demircan S, Memis L, Kurul C, Akyurek N, Turktas H: Pulmonary veno-occlusive disease in a patient with a history of Hashimoto's thyroiditis. Indian J Chest Dis Allied Sci 2005;47:289-292.

43 Gunther S, Jais X, Maitre S, Berezne A, Dorfmuller P, Seferian A, Savale L, Mercier O, Fadel E, Sitbon O, Mouthon L, Simonneau G, Humbert M, Montani D: Computed tomography findings of pulmonary venoocclusive disease in scleroderma patients presenting with precapillary pulmonary hypertension. Arthritis Rheum 2012;64:2995-3005.

44 Morassut PA, Walley VM, Smith CD: Pulmonary veno-occlusive disease and the CREST variant of scleroderma. Can J Cardiol 1992;8: 1055-1058.

-45 Saito A, Takizawa H, Ito K, Yamamoto K, Oka $\mathrm{T}$ : A case of pulmonary veno-occlusive disease associated with systemic sclerosis. Respirology 2003;8:383-385.

-46 D’Souza M, Vergales J, Jayakumar KA: Hypoplastic left heart syndrome and pulmonary veno-occlusive disease in an infant. Pediatr Cardiol 2013;34:1949-1951.

-47 Murakami T, Horigome H, Yamaki S, Nakao T, Hiramatsu Y, Matsui A: Pulmonary venoocclusive disease associated with partial anomalous pulmonary venous connection. Pediatr Int 2003;45:747-750.

-48 Shrivastava S, Moller JH, Edwards JE: Congenital unilateral pulmonary venous atresia with pulmonary veno-occlusive disease in contralateral lung: an unusual association. Pediatr Cardiol 1986;7:213-219.

49 Townend JN, Roberts DH, Jones EL, Davies MK: Fatal pulmonary venoocclusive disease after use of oral contraceptives. Am Heart J 1992;124:1643-1644.

- 50 Urisman A, Leard LE, Nathan M, Elicker BM, Hoopes C, Kukreja J, Jones KD: Rapidly progressive pulmonary venoocclusive disease in young women taking oral contraceptives. J Heart Lung Transplant 2012;31:1031-1036.

51 Tsou E, Waldhorn RE, Kerwin DM, Katz S, Patterson JA: Pulmonary venoocclusive disease in pregnancy. Obstet Gynecol 1984;64: 281-284.

52 Stewart S, Rassl D: Advances in the understanding and classification of pulmonary hypertension. Histopathology 2009;54:104-116.

-53 Wagenvoort CA, Wagenvoort N, Takahashi T: Pulmonary veno-occlusive disease: involvement of pulmonary arteries and review of the literature. Hum Pathol 1985;16:10331041.

54 Thomas de Montpreville V, Dulmet E, Fadel E, Dartevelle P: Lymph node pathology in pulmonary veno-occlusive disease and pulmonary capillary haemangiomatosis. Virchows Arch 2008;453:171-176.

55 Resten A, Maitre S, Humbert M, Rabiller A, Sitbon O, Capron F, Simonneau G, Musset D: Pulmonary hypertension: CT of the chest in pulmonary venoocclusive disease. AJR Am J Roentgenol 2004;183:65-70.
6 Montani D, Price LC, Dorfmuller P, Achouh L, Jais X, Yaici A, Sitbon O, Musset D, Simonneau G, Humbert M: Pulmonary veno-occlusive disease. Eur Respir J 2009;33:189-200.

57 Cope DK, Allison RC, Parmentier JL, Miller JN, Taylor AE: Measurement of effective pulmonary capillary pressure using the pressure profile after pulmonary artery occlusion. Crit Care Med 1986;14:16-22.

58 Scheibel RL, Dedeker KL, Gleason DF, Pliego M, Kieffer SA: Radiographic and angiographic characteristics of pulmonary veno-occlusive disease. Radiology 1972;103:47-51.

59 Swensen SJ, Tashjian JH, Myers JL, Engeler CE, Patz EF, Edwards WD, Douglas WW: Pulmonary venoocclusive disease: CT findings in eight patients. AJR Am J Roentgenol 1996;167:937-940.

60 Miura A, Akagi S, Nakamura K, Ohta-Ogo K, Hashimoto K, Nagase S, Kohno K, Kusano K, Ogawa A, Matsubara H, Toyooka S, Oto T, Ohtsuka A, Ohe T, Ito H: Different sizes of centrilobular ground-glass opacities in chest high-resolution computed tomography of patients with pulmonary veno-occlusive disease and patients with pulmonary capillary hemangiomatosis. Cardiovasc Pathol 2013;22: 287-293.

61 Seferian A, Helal B, Jais X, Girerd B, Price LC, Gunther S, Savale L, Dorfmuller P, Parent F, Sitbon O, Humbert M, Simonneau G, Montani D: Ventilation/perfusion lung scan in pulmonary veno-occlusive disease. Eur Respir J 2012;40:75-83.

62 Elliott CG, Colby TV, Hill T, Crapo RO: Pulmonary veno-occlusive disease associated with severe reduction of single-breath carbon monoxide diffusing capacity. Respiration 1988;53:262-266.

63 Golde DW, Drew WL, Klein HZ, Finley TN, Cline MJ: Occult pulmonary haemorrhage in leukaemia. Br Med J 1975;2:166-168.

64 Barboza CE, Jardim CV, Hovnanian AL, Dias BA, Souza R: Pulmonary veno-occlusive disease: diagnostic and therapeutic alternatives. J Bras Pneumol 2008;34:749-752.

65 Masters K, Bennett S: Pulmonary veno-occlusive disease: an uncommon cause of pulmonary hypertension. BMJ Case Rep 2013, DOI: 10.1136/bcr-2012-007752.

-66 Shackelford GD, Sacks EJ, Mullins JD, McAlister WH: Pulmonary venoocclusive disease: case report and review of the literature. AJR Am J Roentgenol 1977;128:643-648.

67 Matsushita K, Kanna M, Yazawa T, Shimizu S, Nitta M, Takamizawa T, Arakawa K, Yano $\mathrm{H}$, Nishikawa M, Himeno H: Long-term survivor with pulmonary veno-occlusive disease. Circulation 2012;125:e503-e506.

68 Fuster V, Steele PM, Edwards WD, Gersh BJ, McGoon MD, Frye RL: Primary pulmonary hypertension: natural history and the importance of thrombosis. Circulation 1984;70: 580-587.

69 Salzman GA, Rosa UW: Prolonged survival in pulmonary veno-occlusive disease treated with nifedipine. Chest 1989;95:1154-1156.
70 Palmer SM, Robinson LJ, Wang A, Gossage JR, Bashore T, Tapson VF: Massive pulmonary edema and death after prostacyclin infusion in a patient with pulmonary veno-occlusive disease. Chest 1998;113:237-240.

71 Montani D, Jais X, Price LC, Achouh L, Degano B, Mercier O, Mussot S, Fadel E, Dartevelle P, Sitbon O, Simonneau G, Humbert M: Cautious epoprostenol therapy is a safe bridge to lung transplantation in pulmonary venoocclusive disease. Eur Respir J 2009;34:13481356.

72 Ogawa A, Miyaji K, Yamadori I, Shinno Y, Miura A, Kusano KF, Ito H, Date H, Matsubara H: Safety and efficacy of epoprostenol therapy in pulmonary veno-occlusive disease and pulmonary capillary hemangiomatosis. Circ J 2012;76:1729-1736.

73 Ye XQ, Yan CS, Zhang XY, Cai Y, Guo F, Kuang JL: Lengthy diagnostic challenge in a rare case of pulmonary veno-occlusive disease: case report and review of the literature. Intern Med 2011;50:1323-1327.

74 Barreto AC, Franchi SM, Castro CR, Lopes AA: One-year follow-up of the effects of sildenafil on pulmonary arterial hypertension and veno-occlusive disease. Braz J Med Biol Res 2005;38:185-195.

75 Kuroda T, Hirota H, Masaki M, Sugiyama S, Oshima Y, Terai K, Ito A, Yamauchi-Takihara K: Sildenafil as adjunct therapy to highdose epoprostenol in a patient with pulmonary veno-occlusive disease. Heart Lung Circ 2006;15:139-142.

-76 Creagh-Brown BC, Nicholson AG, Showkathali R, Gibbs JS, Howard LS: Pulmonary venoocclusive disease presenting with recurrent pulmonary oedema and the use of nitric oxide to predict response to sildenafil. Thorax 2008; 63:933-934.

77 Montani D, Jais X, Dorfmuller P, Simonneau G, Sitbon O, Humbert M: Goal-oriented therapy in pulmonary veno-occlusive disease: a word of caution. Eur Respir J 2009;34:12041206.

-78 Sanderson JE, Spiro SG, Hendry AT, TurnerWarwick M: A case of pulmonary veno-occlusive disease respondong to treatment with azathioprine. Thorax 1977;32:140-148.

-79 Izbicki G, Shitrit D, Schechtman I, Bendayan D, Fink G, Sahar G, Saute M, Ben-Gal T, Kramer MR: Recurrence of pulmonary venoocclusive disease after heart-lung transplantation. J Heart Lung Transplant 2005;24:635637.

80 Strueber M, Hoeper MM, Fischer S, Cypel M, Warnecke G, Gottlieb J, Pierre A, Welte T, Haverich A, Simon AR, Keshavjee S: Bridge to thoracic organ transplantation in patients with pulmonary arterial hypertension using a pumpless lung assist device. Am J Transplant 2009;9:853-857. 
81 Hoopes CW, Gurley JC, Zwischenberger JB, Diaz-Guzman E: Mechanical support for pulmonary veno-occlusive disease: combined atrial septostomy and venovenous extracorporeal membrane oxygenation. Semin Thorac Cardiovasc Surg 2012;24:232-234.

82 Corbacioglu S, Cesaro S, Faraci M, ValteauCouanet D, Gruhn B, Rovelli A, Boelens JJ, Hewitt A, Schrum J, Schulz AS, Muller I, Stein J, Wynn R, Greil J, Sykora KW, Matthes-Martin S, Fuhrer M, O'Meara A, Toporski J, Sedlacek P, Schlegel PG, Ehlert K, Fasth A, Winiarski J, Arvidson J, Mauz-Korholz C, Ozsahin $\mathrm{H}$, Schrauder A, Bader P, Massaro J, D’Agostino R, Hoyle M, Iacobelli M, Debatin KM, Peters C, Dini G: Defibrotide for prophylaxis of hepatic veno-occlusive disease in paediatric haemopoietic stem-cell transplantation: an open-label, phase 3, randomised controlled trial. Lancet 2012;379:1301-1309.

83 Richardson PG, Soiffer RJ, Antin JH, Uno H, Jin Z, Kurtzberg J, Martin PL, Steinbach G,
Murray KF, Vogelsang GB, Chen AR, Krishnan A, Kernan NA, Avigan DE, Spitzer TR, Shulman HM, Di Salvo DN, Revta C, Warren D, Momtaz P, Bradwin G, Wei LJ, Iacobelli M, McDonald GB, Guinan EC: Defibrotide for the treatment of severe hepatic veno-occlusive disease and multiorgan failure after stem cell transplantation: a multicenter, randomized, dose-finding trial. Biol Blood Marrow Transplant 2010;16:1005-1017.

84 Willems E, Canivet JL, Ghaye B, de Leval L, Radermecker M, Preiser JC, Beguin Y: Pulmonary veno-occlusive disease in myeloproliferative disorder. Eur Respir J 2009;33:213216.

85 Ghofrani HA, Morrell NW, Hoeper MM, Olschewski H, Peacock AJ, Barst RJ, Shapiro S, Golpon H, Toshner M, Grimminger F, Pascoe S: Imatinib in pulmonary arterial hypertension patients with inadequate response to established therapy. Am J Respir Crit Care Med 2010;182:1171-1177.
86 Hoeper MM, Barst RJ, Bourge RC, Feldman J, Frost AE, Galie N, Gomez-Sanchez MA, Grimminger F, Grunig E, Hassoun PM, Morrell NW, Peacock AJ, Satoh T, Simonneau G, Tapson VF, Torres F, Lawrence D, Quinn DA, Ghofrani HA: Imatinib mesylate as add-on therapy for pulmonary arterial hypertension: results of the randomized IMPRES study. Circulation 2013;127:1128-1138.

87 Overbeek MJ, van Nieuw Amerongen GP, Boonstra A, Smit EF, Vonk-Noordegraaf A: Possible role of imatinib in clinical pulmonary veno-occlusive disease. Eur Respir J 2008;32:232-235.

88 Koiwa H, Tsujino I, Ikeda D, Ohira H, Tanino M, Nishimura M: An autopsy case of pulmonary veno-occlusive disease refractory to imatinib. Eur Respir J 2011;37:968-970.

89 Kataoka M, Yanagisawa R, Fukuda K, Yoshino $\mathrm{H}$, Satoh T: Sorafenib is effective in the treatment of pulmonary veno-occlusive disease. Cardiology 2012;123:172-174. 